\title{
Khuntsa dalam Pandangan Kontemporer
}

\author{
Ilham Ghoffar Solekhan ${ }^{1}$, Maulidi Dhuha Yaum Mubarok ${ }^{2}$ \\ 1,2 Magister Ilmu Syari'ah, UIN Sunan Kalijaga Yogyakarta \\ e-mail: ilham.solekhan@gmail.com,maulidi159@gmail.com
}

\begin{abstract}
ABSTRAK: Khuntsa adalah suatu keadaan ketika seorang individu memiliki dua kelamin dan tidak dapat diidentifikasikan apakah dia perempuan dan laki-laki. Khuntsa dibedakan menjadi dua macam, 1) Khuntsa Musykil yaitu suatu keadaan kelamin ganda yang penentuan kelaminnya sangat sulit, 2) Khuntsa Gahiru Musykil yaitu keadaan kelamin ganda yang masih dapat dengan mudah diidentifikasikan kelaminnya. Fikih baru masih menggunakan pengertian lama mengenai khuntsa. Meskipun demikian, khuntsa di dunia modern dianggap sebagai anomali kelamin yang memungkinkan dan dapat terjadi pada beberapa orang. Keadaan khuntsa juga memunculkan teori psikologi yang menunjukkan bahwa keadaan ini dapat menjadi pemicu masalah psikologis bagi individu khuntsa tersebut yang dapat berpengaruh terhadap fisik dan perilaku. Dunia kedokteran modern mengkategorikan khuntsa sebagai anomali kelamin yang dapat diidentifikasikan, dan dapat ditangani. Penanganan yang disarankan adalah prosedur yang sama seperti pada pergantian kelamin. Meskipun bertentangan dengan fikih klasik, namun dalam fikih kontemporer hal tersebut dapat terjadi dengan pertimbangan. Salah satu pertimbangan yang diberikan adalah kaidah fikih yaitu الضرر يزال yang juga merupakan dalil yang kuat untuk membuktikan pentingnya penetapan status bagi khuntsa. Tulisan ini menggunakan metode penelitian pustaka atau literature review dengan menggunakan pendekatan normatif sosiologis dan teologis yang menjelaskan pokok persoalan dalam pandangan hukum Islam dan hukum positif, masyarakat dan sisi ketuhanan.
\end{abstract}

Kata kunci: Khuntsa, Perubahan Kelamin, Penetapan Status.

\section{PENDAHULUAN}

Masalah-masalah terkait dengan khuntsa dewasa ini semakin banyak dibahas dan begitu kompleks. Salah satu dari sekian banyak permasalahan khuntsa yang diangkat adalah kedudukan khuntsa dalam ahli waris yang disampaikan oleh Ni Luh Tanzila Yuliasri dalam artikel yang berjudul "Kedudukan Ahli Waris Khuntsa dalam Hukum Waris Islam", ${ }^{1}$ menyimpulkan dalam artikel tersebut, bahwa penetapan status khuntsa merupakan tahap yang harus diselesaikan terlebih dahulu sebelum menentukan kedudukannya sebagai ahli waris.

Lebih lanjut, dalam hal perkawinan khuntsa, Bagus Prasetyo dalam karya ilmiahnya menjelaskan bahwa seorang khuntsa tidak dapat melangsungkan perkawinan karena belum memiliki status jenis kelamin yang jelas, perkawinan dapat dilangsungkan apabila status kbuntsa telah jelas. ${ }^{2}$

${ }^{1}$ Ni Luh Tanzila Yuliasri. "Kedudukan Ahli Waris Khuntsa dalam Hukum Waris Islam." Mimbar Keadilan, Vol. 14, No. 28, (1 Agustus 2018): 219. https://doi.org/10.30996/mk.v0i0.1781

2 Bagus Prasetyo Purnomo Putro, "Tinjauan Yuridis Perkawinan Al-Khuntsa (Kelamin Ganda) Menurut Hukum Islam," (Skripsi Sarjana, Universitas Jember, 2013): 2-3. 
Secara terminologis, khuntsa atau yang lebih sering kita sebut berkelamin ganda adalah manusia yang tidak dapat digolongkan ke dalam gender normal yaitu, laki-laki atau perempuan. Hal ini dikarenakan, kbuntsa adalah orang yang memiliki kedua kelamin (dzakar dan farji) yang selama ini menjadi patokan dalam menentukan gender seseorang agar dapat dikenakan aturan syara' yang sesuai dengan kodratnya. Kemunculan kelamin ganda pada orang-orang tertentu, berdampak pada bagaimana aturan syara' dapat diterapkan kepadanya. Apalagi yang kaitannya dengan hal - hal yang sifatnya fundamental. Selain dari segi syara', dampak yang dapat ditimbulkan dari adanya kasus khuntsa ini adalah permasalahan sosial, yaitu penerimaan masyarakat akan ketidakjelasan statusnya ini, begitu pula dalam permasalahan lain seperti hukum.

Penanganan atas kasus kelamin ganda ini diatasi secara signifikan hanya pada negaranegara maju, seperti Jerman yang telah mengatasi permasalahan khuntsa sejak dua tahun kelahiran seorang bayi. Namun, hal ini tidak terjadi di Indonesia, masalah khuntsa atau kelamin ganda di Indonesia tidak menjadi sebuah permasalahan yang ditangani secara baik dan benar. Banyaknya kasus kelamin ganda di Indonesia hanya cenderung dibiarkan dan akhirnya menjadi masalah yang pelik di masyarakat. Seseorang yang berkelamin ganda di Indonesia dihinggapi berbagai masalah sosial, seperti dipandang sebelah mata di lingkungannya, hingga ke stereotip mitos bahwa orang yang berkelamin ganda adalah orang yang dikutuk. Maka dari itu, permasalahan kbuntsa atau kelamin ganda kini, terkhusus di Indonesia, tidak hanya berhenti pada bagaimana syara' ditetapkan padanya, namun juga sampai kepada bagaimana penegasan status dari kejanggalan kelamin yang dialami oleh khuntsa.

Dengan demikian, menjadi sebuah pekerjaan khusus untuk menempatkan kbuntsa sebagaimana semestinya. Selain itu, menemukan dan menetapkan status dari khuntsa meski tidak dengan menjalani upaya upaya medis menjadi konsen yang sangat penting, mengingat status dari seorang manusia, baik laki-laki maupun perempuan, adalah patokan yang sangat penting. Masalah-masalah keperdataan contohnya seperti waris, nikah dan lain sebagainya menjadi lebih jelas, baik bagi khuntsa itu sendiri maupun masyarakat. Oleh karena hal tersebut, penulis mengangkat permasalahan ini sebagai bentuk konsen terhadap pentingnya penetapan status seorang khuntsa serta pandangan kontemporer terhadapnya.

Kelamin yang menjadi perdebatan adalah khuntsa, yang merupakan kelainan kelamin yang menyebabkan ketidakjelasan kelamin. Khuntsa berasal dari kata khanatsa, yang berarti pecah atau lemah. Dalam kamus kontemporer Arab Indonesia karangan Ali Attabik yang dimaksud Khuntsa secara bahasa berasal dari kata خنثا يخنث خنث yang berarti seperti perempuan. ${ }^{3}$ Sedang secara terminologis, khuntsa adalah orang yang diragukan dan tidak diketahui apakah dia laki-laki atau perempuan. ${ }^{4} \mathrm{Hal}$ ini dapat dikarenakan dia memiliki dzakar dan farji, atau dapat pula karena dia sama sekali tidak memiliki dqakar atau farji. Wahbah Zuhaili menyebutkan bahwa kbuntsa adalah

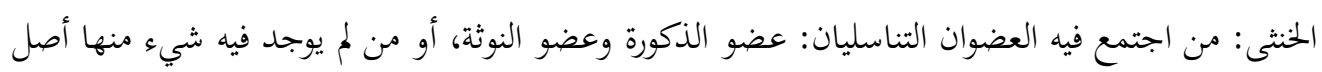

Khuntsa: orang yang padanya berkumpul dua alat kelamin, yaitu kelamin laki-laki dan kelamin perempuan atau tidak didapati satupun dari keduanya (kelamin laki-laki atau perempuan) sama sekali. ${ }^{5}$

${ }^{3}$ Atabik Ali dan A. Z. Muhdor, "Kamus Kontemporer" (Yogyakarta: Yayasan Ali Maksum Pondok Pesantren Krapyak, 1996), 86.

${ }^{4}$ Sayyid Sabiq, Fiqih Sunnah, alih Bahasa Nor Hasanuddin, Cet. 3, (Kairo: Dar Al-Fath, 2004), 513.

${ }^{5}$ Wahbah az-Zuhaili, al-Fiqhu al-Islami wa Adilatuhu, Dar al-Fiker, Cet II, Jilid VIII, (Beirut: Darul Fikr 1985), 426. 
Sayyid Sabiq juga memberikan pengertian mengenai khuntsa sebagai berikut

$$
\text { الخنثى: شخص اشتبه فن أمره ولم يدر أذكر هو أم أنثى، إما لن له ذكرا و فرجا معا اولنه ليس له شيء منهما أصل }
$$

Khuntsa: seorang yang tidak.jelas perkara dirinya (keadannya) dan tidak diketabui apakah dia laki-laki atau perempuan. Hal ini dikarenakan dia memiliki kelamin laki-laki dan perempuan sekaligus atau babkan karena tidak terdapat tanda-tanda kelamin sama sekali dari keduanya (laki-laki atau permpuan). ${ }^{6}$

Kepemilikan atas kedua alat kelamin yang dimiliki oleh khuntsa tersebut tidak lantas menempatkan khuntsa sebagai jenis kelamin ketiga. Pada akhirnya, Khuntsa merupakan masalah yang menjadi sorotan karena memang dalam kajian hukum Islam beserta penerapannya, ditetapkan bahwa hanya ada dua kelamin saja yaitu laki-laki atau perempuan. Meskipun seseorang memiliki kelamin ganda hanya dapat mengikuti aturan hukum secara perempuan atau laki-laki, tidak boleh keduanya.

\section{METODOLOGI}

Tulisan ini didasarkan pada metode normatif-teologis yang mengemukakan pendapat sebagian ahli fikih baik yang berwawasan fikih klasik maupun modern. Metode ini bermaksud menggali makna khuntsa dan perlakuan fikih terhadap fenomena kbuntsa yang sudah ada sejak dulu kala. Tulisan ini mengedapankan pendekatan sosiologis, sehingga penelitian ini lengkap pandangannya dan bisa dikritisi dari berbagai sudut pandang.

Data dalam tulisan ini diperoleh melalui penelitian pustaka atau literature review dengan menggunakan pendekatan normatif sosiologis dan teologis yang menjelaskan khuntsa dalam pandangan hukum Islam dan hukum positif, masyarakat dan sisi ketuhanan. Selain itu, pendekatan normatif, sosiologis digunakan untuk memandang orang khuntsa sebagai seseorang yang dipandang sebelah mata dan bahkan dikucilkan. Dengan demikian pandangan kontemporer tentang kbuntsa haruslah mengakomodir kbuntsa tersebut dan menempatkan khuntsa dan segala permasalahannya dalam tatanan modern. Sehingga tidak lagi menjadi sesuatu hal yang muncul, kemudian hilang terlupakan.

\section{PEMBAHASAN DAN DISKUSI}

\section{Status Khuntsa}

Khuntsa sering dikaitkan dengan waria atau seseorang yang mengalami kelainan psikologis, dan dipersamakan dengan transeksual serta transgender. Padahal secara prinsip semua istilah tersebut memiliki arti dan maksud yang berbeda, bukan hanya makna dari istilah, namun juga secara nyata berbeda maksud. Telah disampaikan sebelumnya bahwa kbuntsa dalam istilah adalah orang yang mempunyai alat kelamin laki-laki dan perempuan atau bahkan tidak memiliki keduaduanya sama sekali. Dengan demikian, kbuntsa ditempatkan pada ranah yang tidak dapat memilih karena datangnya dari pencipta sendiri. Mengenai berbagai kerancuan yang ada dapat kita perhatikan pendapat para ahli terutama dalam kajian psikologi dan kedokteran karena permasalahan mengenai istilah yang salah ini berkaitan dengan kajian dalam disiplin tersebut.

\footnotetext{
${ }^{6}$ Sabiq, Fiqib Sunnah..., 313.
} 
Sedangkan waria adalah sebuah kondisi seseorang yang memiliki kondisi fisiologis laki-laki, namun cenderung untuk berfikir, berpenampilan dan berperilaku layaknya perempuan. Waria cenderung untuk melakukan penyimpangan seksual seperti transeksual dan transgender. Transeksual merupakan sebuah kecenderungan untuk mengganti kelamin karena merasa bahwa identitas gendernya berlawanan dengan kondisi biologis yang dimilikinya. Transeksual merasa bahwa dirinya 'terperangkap' pada tubuh yang salah sehingga menghendaki untuk membenarkannya.

Transeksual dan trangender hampir didefinisikan secara sama, namun transeksual lebih mengarah kepada dorongan untuk melakukan usaha demi mewujudkan gender yang diinginkan semisal dengan operasi kelamin. Anindita menyebutkan dalam tulisannya yang dimuat oleh Jurnal Kriminologi Indonesia menyebutkan bahwa transgender adalah orang yang tidak berpenampilan sama dengan gender yang telah melekat pada dirinya sejak lahir. Sedang transeksual adalah indvidu yang secar hormonal atau pembedahan melakukan perubahan pada alat kelamin dan tubuhnya.

Gay, Lesbian, Straight, Education Network (GLSEN) memberi definisi terkait transgender dan transeksual, bahwa transgender adalah paying untuk individu yang berekspresi tidak sesuai dengan gender seksnya. Transeksual adalah salah satu contoh dari transgender yang cenderung melakukan operasi kelamin atau hormon untuk melakukan perubahan kepada gender yang diinginkan. Definisi yang dipaparkan GLSEN tersebut dapat ditarik kesimpulan bahwa Trangender adalah sebuah kata umum untuk pengidap dysphoria gender, sedang transeksual adalah contoh dari transgender.

Khuntsa dalam pembahasan fiqh dibedakan menjadi dua macam, yaitu Khuntsa Musykil dan Khuntsa Ghairu Musykil yang keduanya memiliki definisi yang berbeda. Perbedaan ini dimaksudkan untuk lebih mudah mengelempokkan khuntsa berdasar jenis kasusnya.

\section{Khuntsa Musykil}

Khuntsa musykil adalah khuntsa yang dengan segala macam cara pembuktian tidak dapat ditentukan atau dipatikan jenis kelaminnya. ${ }^{7}$ Khuntsa musykil juga dapat dikatakan sebagai kbuntsa yang kedua kelaminnya berfungsi dengan baik dan tidak ada kendala. ${ }^{8}$ Dengan demikian, kbuntsa musykil ini tidak dapat diteliti dan ditentukan secara pasti hukum yang dapat ditetapkan kepadanya karena ketidakdominanan salah satu dari kedua kelamin yang ada (keduanya samasama menonjol).

\section{Khuntsa Ghairu Musykil}

Khuntsa ghairu musykil adalah khuntsa yang melalui alat yang ada dapat dipastikan jenis kelaminnya. Jika dengan sebuah alat, dapat dipastikan dia adalah laki-laki, maka alat kelamin lain adalah tambahan. Penetapan kelamin dari khuntsa ghairu musykil ini juga dapat dilakukan dengan memperhatikan dari mana urine tersebut keluar. Jika, urine/air kencing keluar dari keduanya, maka dapat dilihat dari manakah air kencing pertama keluar. Jika air kencing yang keluar melewati dzakar terlebih dahulu daripada lewat farji, maka dia dianggap seorang laki-laki dan dihukumi dengan hukum untuk laki-laki. Sebaliknya, apabila air kencing keluar dari farji dahulu

\footnotetext{
7 Amir Syarifuddin, Hukum Kewarisan Islam, (Jakarta: Prenada Media, 2004), 140.

${ }^{8}$ Fathur Rahman, Ilmu Waris. (Bandung: al-Ma'arif, 1975), 482.
} 
daripada dari dzakar, maka dia dianggap seorang perempuan dan dihukumi dengan hukum untuk perempuan. ${ }^{9}$

Dengan demikian, para mujtahid menentukan dua cara untuk menentukan kelamin dari khuntsa.

a. Alat Keluarnya Kelamin

Metode pertama untuk menentukan kelamin dari khuntsa adalah dengan mempelajari darimana keluar air kencingnya. Kasus mudah seperti khuntsa ghairu musykil mungkin akan sangat jelas untuk diketahui darimana air kencingnya keluar karena alat kelamin yang berfungsi hanya satu meskipun dia memiliki dua alat kelamin. Ketidakfungsian alat kelamin yang satu dapat karena memang hanya sebuah anomali dalam pembentukan alat kelamin jadi tidak menjadi hal yang menyulitkan. Berbeda dengan khuntsa musykil yang kedua alat kelaminnya sama-sama berfungsi dengan baik dan keduanya dapat mengeluarkan air kencing. Dalam kasus ini maka yang perlu diperhatikan adalah alat kelamin mana yangmengeluarkan air kencing lebih dahulu. Apabila air kencing dikeluarkan lebih dahulu dari dzakar daripada dari farj, maka dapat dianggap bahwa dia (khuntsa tersebut) adalah seorang laki-laki. Begitupun sebaliknya apabila air kencing lebih dahulu keluar dari farj daripada dari dzakar, maka dia dianggap sebagai laki-laki dan dapat diperlakukan sebagai laki-laki. ${ }^{10}$

Metode ini berdasarkan hadis Rasulullah SAW yang beliau sampaikan ketika beliau menimang bayi dari kalangan Anshar yang berkelamin ganda:

$$
\text { فقال، أتي بخنثى من النصارُ روي أنه صلى الله عليه وسلم أثوهّور من اول مايبول منه }
$$

"Diriwayatkan bahwa Rasul SAW bertemu dengan khuntsa dari kalangan Anshar, maka beliau bersabda: Berilah warisan anak khuntsa ini (seperti bagian anak. lakilaki atau perempuan) mengingat dari alat kelamin yang mula pertama dipergunakannya berkencing""11

Hadis senada juga disebutkan dalam Al-Kaafi karangan Syekh Kulaini, sebagai berikut: ${ }^{12}$

$$
\begin{aligned}
& \text { عن صفوان بن يميى، عن محمد بن عبد الجبار، أبو علي الشعري عن داود بن، عن ابن مسكان، عن صفوان، عن } \\
& \text { الفضل بن شاذان جميعا، إسماعيل عن أبي عبد الله عليه السلام قال: سئل عن مولود ولد وله قبل وذكر كيف، فرقد } \\
& \text { وإن كان يبول من القبل فله، يورث؟ قال: إن كان يبول من ذكره فله ميراث الذكر ميراث النثى }
\end{aligned}
$$

'Dari Abu Ali Al-Asy'ari, dari Abdul Jabar, dari Sofwan bin Yabya, dan Muhammad bin Ismail, dari Fadbil bin Sadzan keduanya, dari Sofwan, dari Ibnu Maskan, dari Dawnd bin Farqad, dari Abi Abdillah Alaibi Salam berkata: Ditanya tentang kelabiran seorang bayi dan dia memilki vagina dan dzakar bagaimana warisannya? Beliau berkata: "apabila dia kencing dari dzakar maka dia mewarisi sebagaimana warisannya laki-laki, dan apabila dia kencing dari vagina maka baginya warisan seperti warisannya perempuan"

b. Meniliti Tanda - Tanda Kedewasaan

\footnotetext{
${ }^{9}$ Ibid., 379.

${ }^{10}$ Ibid., 483.

${ }^{11}$ Shalih bin Abdul Aziz, at-Takmil Mafata Tabribihi min Idwaul Ghalil., (Riyadh: Darul Asshimat, 1996), 110.

12 Kulaini, al-Kaafi, Juz 7, (Iran: Darul Kitab Islamiyah, 1367), 156.
} 
Metode pertama dalam menentukan jenis kelamin bagi khuntsa dianggap sebagai metode yang paling mudah untuk dilakukan karena dapat dilakukan dengan jenjang usia yang tidak tentu. Namun, apabila metode pertama tidak berhasil untuk menentukan kelamin khuntsa, maka dapat menggunakan metode lain, yaitu meneliti tanda - tanda kedewasaannya. Seperti telah diketahui secara luas bahwa terdapat ciri-ciri kedewasaan yang berbeda antara laki-laki dan perempuan (secara fisik), meskipun adapula ciri kedewasaan yang sama. Ulama - ulama berbagai madzhab berkomentar dalam kaitannya dengan penentuan kelamin dari khuntsa adalah sebagai berikut: ${ }^{13}$

1) Hanabilah dan salah satu dari ulama Syafi'i berpendapat bahwa penentuan tersebut dilihat dari alat kelamin mana yang lebih banyak mengeluarkan air kencing. Alasan dari pendapat ini adalah karena menghukumi dengan keadaan mayoritas sebagai hukum keseluruhan adalah termasuk pondasi Syariah.

2) Hanafiyah dan satu ulama syafi'i serta salah satu pendapat hanabilah mengatakan bahwa khuntsa tetap dihukumi dengan khuntsa karena tidak ada tanda-tanda yang menguatkan (dalam perkara khuntsa musykil). Mereka menambahkan bahwa banyaknya air kencing yang keluar dari salah satu alat kelamin bukan tanda yang jelas dari alat kelamin asli khuntsa.

3) Ibnu Utsaimin memiliki pendapat bahwa menggunakan metode kedokteran dibolehkan dalam penentuan kelamin dari khuntsa, contohnya dengan melakukan pengecekan terhadap rahimnya.

Ilmu kedokteran membahas masalah khuntsa ini sebagai sebuah keadaan kelamin yang abnormal. Kelainan kelamin seperti halnya khuntsa dikenal dan diteliti serta diberi istilah ambiguous genatalia. Ambiguous genitalia atau sex ambignity adalah suatu kelainan di mana penderita memiliki ciri-ciri genetik, anatomik dan atau fisiologik meragukan antara laki-laki dan perempuan. ${ }^{14}$

Dalam bahasa Indonesia hal ini disebut dengan jenis kelamin meragukan atau membingungkan. Disebut pula dengan kelamin ganda karena kadang-kadang klitoris sangat besar sehingga tampak seperti ada dua kelamin. Selain dengan sebuatan di atas, kelainan ini dikenal juga dalam istilah ilmiah yang lain sebagai interseksual, istilah yang mengacu pada pengertian bahwa jenis kelamin terbagi menjadi dua kutub, laki-laki atau perempuan, jadi bentuk kelamin yang meragukan berada di antara dua kutub tersebut.

Namun pada perkembangannya, saat ini para ahli endokrinologi, ${ }^{15}$ lebih sering menggunakan istilah Disorders of Sexual Development (DSD). Seperti diketahui bahwa pada pembentukan kelamin yang terjadi dalam Rahim didasari pada dominasi suatu kromosom yang saling bersilang. Pada pembentukan kelamin pria, daerah pada kromosom Y memicu perkembangan testis, yang menghasilkan hormon pria. Alat kelamin laki-laki berkembang sebagai respons terhadap hormon laki-laki dari testis janin. Sebaliknya, pada pembentukan kelamin perempuan, jika pada janin tanpa kromosom $\mathrm{Y}$, artinya hanya ada kromosom $\mathrm{X}$ yang bersilang dari ayah dan ibu dan juga tanpa efek hormon laki-laki, alat kelamin berkembang

13 Bagus Prasetyo Purnomo Putro, Tinjanan Yuridis Perkawinan..., 2.

${ }^{14}$ Kate Davies, "Disorders of Sex Development-Ambiguous Genitalia." Journal of Pediatric Nursing 31, No. 4 (Juli 2016): 46-66.

${ }^{15}$ Devie Lya Saraswati, "Eksplorasi Kepribadian Waria dalam Perspektif Psikologi Individual.” Jurnal Riset Mahasiswa Bimbingan dan Konseling 1 (2017): 19. 
sebagai perempuan. Hal ini disebabkan karena pada dasarnya pembentukan kelamin antara lakilaki adalah sama hanya bagaimana proses pembentukan tersebut berlangsung.

Kasus terkait ambiguous genatalia, terjadi karena terdapat gangguan pada langkah-langkah yang menentukan jenis kelamin yang akhirnya mengakibatkan ketidakcocokan antara penampilan alat kelamin eksternal dan organ intim internal atau jenis kelamin genetik (XX atau $\mathrm{XY}$ ). Penyebab lain dapat terjadi juga karena kekurangan hormon laki-laki pada janin laki-laki secara genetik. Sebaliknya, terpapar hormon laki-laki selama perkembangan kelamin pada janin perempuan menghasilkan genitalia atau pembentukan alat kelamin yang ambigu pada wanita secara genetik. Mutasi pada gen tertentu dapat mempengaruhi perkembangan seks janin dan menyebabkan keanehan pada alat kelamin. Kelainan kromosom, seperti kromosom seks yang hilang atau berlebih, dapat juga menyebabkan kelainan alat kelamin. Dalam beberapa kasus, penyebab terjadinya keambiguan alat kelamin tidak dapat ditentukan secara tepat. Namun kemungkinan yang masuk akal adalah penyebabnya terdapat pada genetik perempuannya. ${ }^{16}$

Pihak medis, dalam mendiagnosa adanya kelainan DSD tidak serta-merta, karena pada dasarnya tidak mudah mendiagnosis DSD dan menetapkan kelamin begitu saja. Selain itu diagnose juga dapat menjadi susah dilakukan jika perubahan eksternal tidak jelas, misal kelamin lebih cenderung ke arah salah satu kelamin, atau tumbuhnya bagian tubuh yang mendukung kelamin tertentu. Evaluasi diagnosis harus dilakukan dalam kasus DSD atau ambiguous genitalia ini guna: 1) menetapkan jenis kelamin genetik (dari kedua kelamin yang ada); 2) mengetahui kadar hormonal beserta lingkungan yang cocok dengan hormone yang berkembang; 3) mengevaluasi anatomi dari ciri kelamin internal dan eksternal serta bakal alat reproduksi; 4) mengevaluasi jenis kelamin fenotipik dan psikologis. Ketika segala hal telah dilakukan dan melakukan evaluasi diagnosa yang benar, maka alat kelamin yang berlawanan dengan hal-hal tersebut harus dikeluarkan. ${ }^{17}$

\section{Perubahan Status}

Islam menjelaskan tentang perubahan kelamin sebagai isu yang dikaji dalam fikih modern, karena adanya pemikiran untuk merubah kelamin ada pada era modern yang memungkinkan dilakukannya perubahan kelamin, meskipun zaman dulu juga terdapat pula perilaku seperti perubahan kelamin seperti kebiri yaitu menghilangkan kelamin yang melekat padanya. Fuqaha telah merumuskan bahwa berganti kelamin (dalam hal ini kaitannya dengan segala perubahan kelamin. Al-Qur'an Surat an-Nisa' ayat 119, Allah melarang untuk mengadakan perubahan pada ciptaan yang telah Allah tetapkan, seperti halnya juga pada kelamin karena merupakan ketetapan yang telah ditetapkan oleh Allah sejak dia lahir ke dunia.

Telah disebutkan dalam kitab-kitab tafsir seperti Thabari, Al-Shawi, Al-Khazin, ALBaidhawi, Zubdatul Tafsir dan Shafwatul Bayan yang dituliskan oleh Masjfuk Zuhdi dalam bukunya Masailul Fighiyah: Kapita selekta Hukum Islam, bahwa perbuatan yang diharamkan karena merupakan tindakan perubahan ciptaan Allah adalah mengebiri manusia, homoseksual, lesbian, menyambung rambut dengan sopak, pangur, membuat tatto, mencukur bulu muka (alis), dan thakannuts, yaitu bertingkah laku seperti jenis kelamin lawannya atau transeksual, atau yang biasa kita sebut banci atau tomboy. Beberapa hadis juga menunjukkan ketidakbolehan dari merubah

16 Kate Davies, Disorders of Sex ..., 57.

${ }^{17}$ Edy Susanto, Hermaphrodite Sejati, Majalah Obsteri \& Ginekologi, Vol. 21, No. 1, (Januari-April, 2013), 36. 
ciptaan Allah. Bahkan dalam beberapa hadis melarang dengan pasti untuk menyerupai lawan jeniskebiri, mengubah kelamin dari laki-laki ke perempuan atau sebaliknya) merupakan sesuatu yang tidak dapat dilakukan bahkan derajatnya ada pada taraf haram. Para fuqaha mendasarkan keputusan ini berdasarkan dalil yang menjadi isyarat tentang keharaman melakukan perubahan kelamin baik secara eksplisit ataupun impilisit.

Pada dasarnya, hukum dari operasi kelamin, tidak seketika haram, karena dalam hukum Islam dikenal juga kriteria dari sebuah perbuatan sehingga dapat dipersamakan illat-nya atau faktor yang mendasari suatu perbuatan itu dapat diklasifikasikan sebagai haram atau mubah. Terlebih pada perkara-perkara kontemporer, seperti merubah kelamin dengan cara operasi dan lain sebagainya. Sebagai contoh perubahan kelamin dalam kasus khuntsa atau hermaphrodite yang menempatkan perubahan tersebut bersifat perbaikan atau penyempurnaan. Hal ini diindikasikan karena khuntsa atau hermaphrodit dapat dipastikan memiliki kelamin dominan dari keduanya, meskipun dalam kasus khuntsa musykil hal tersebut sulit sekali diketahui, namun tetap dapat dilakukan. Perubahan ini dapat dilakukan dan diperbolehkan hukum Islam, karena sifatnya yang memungkinkan untuk merubahnya, yaitu alasan kelamin ganda, dan kebolehan ini dapat berubah menjadi kewajiban apabila dihadapkan pada situasi yang menyebabkan salah satu kelamin dari khuntsa berbahaya bagi kesehatan tubuhnya. ${ }^{18}$

Perubahan yang menuju kearah penyempurnaan atau perbaikan ini harus melihat juga kelamin yang didalam tubuh, bukan hanya yang terlihat secar fisik. Sebagai contoh ada atau tidaknya ovarium dan rahim, atau buah dzakar, sehingga arah operasinya tidak salah arah. Selain itu juga diperbolehkan dengan kondisi kelamin yang kurang sempurna bentuknya, contohnya orang tersebut memiliki vagina yang tidak memiliki lubang, namun dia memiliki rahim dan ovarium, maka dia boleh menyempurnakan kelamin tersebut dengan menambahkan lubang pada vaginanya. ${ }^{19}$ Begitu pula sebaliknya, seseorang yang memiliki penis, namun lubang penisnya tidak berada diujung melainkan di bawahnya, maka diperbolehkan untuk dibuatkan lubang dibagian depan penisnya.

Pembahasan dalam al-jirahat ('amaliyat) al-Tajmiliyyat dibahas bahwa kebolehan mengoperasi bagian tubuh atau dengan kata lain melakukan rekontruksi pada tubuh memiliki persyaratan yang harus ditempuh lebih dahulu, agar tidak terjadi sesuatu yang tidak diinginkan. Syaratnya adalah sebagai berikut, dan juga syarat - syarat ini haruslah terdapat secara pasti dan bersifat kumulatif, bukan dipenuhi hanya satu, namun kesemuanya juga harus dipenuhi sebelum melakukan rekronstruksi pada tubuh:

1) Bahan yang dipergunakan untuk menambal atau menutupi cacat, seperti kulit, tulang atau organ lainnya, harus berasal dari tubuhnya sendiri atau dari seseorang yang telah meninggal dunia. Ulama memberikan batasan dalam pengambilan organ atau jaringan orang yang baru meninggal adalah dari analogi (qiyas) dari pendapat jumhur ulama terhadap pembolehan makan daging mayat dalam keadaan darurat. Pendapat ini didasari dari kaidah fiqhiyyah الضررلا يزال بم تلكه (madharat tidak boleh dihilangkan dengan sesuatu yang madharat). Syarat ini didasari pada fakta atau keadaan ketika bedah rekronstuksi ini membutuhkan tambahan bagian tubuh seperti daging, kulit atau tulang. Tidak diperkenankan untuk memakai bahan atau mengambil bahan

18 Zuhroni, dkk., Islam untuk Disiplin Ilmu Kesehatan dan Kedokteran 2, (Jakarta: Departemen Agama RI, 2003), 199.

${ }^{19}$ Masjfuk Zuhdi, Masail Fiqhiyyah: Kapita Selekta Hukum Islam, (Jakarta: CV. Haji Masagung, 1991), 167. 
tambahan tersebut dari manusia yang masih hidup karena hal tersebut merupakan hal yang dharar, sehingga harus dihindarkan penggunannya. Namun, apabila tidak dibutuhkan tambahan, maka syarat ini dapat dikecualikan.

2) Dokter yang menangani pembedahan itu harus merasa yakin bahwa tindakannya akan berhasil. Persyaratan ini harus mutlak ada dalam setiap operasi rekonstruksi anggota tubuh, karena dokter adalah seorang yang menjadi sarana dari operasi ini. Syarat ini berangkat dari kaidah fikih الضرريزال (Ke-madharat-an harus dihilangkan). Ketidakahlian dari dokter dalam menangani bedah rekronstuksi menjadi sebuah kedhararan yang harus dihindarkan, maka syarat ini menjadi mutlak adanya.

Indonesia sebagai negara hukum, telah menempatkan perubahan kelamin sebagai objek hukum, meskipun tidak disebutkan secara eksplisit langsung dalam Undang-undang. Pada Undang - Undang Nomor 24 tahun 2013 tentang Administrasi Kependudukan disebutkan beberapa hal penting terkait pergantian kelamin, seperti dalam pasal 1 angka 17 dan pasal 56 ayat 1 undang - undang tersebut: ${ }^{20}$

Pasal 1 angka 17:

"Peristiwa penting adalah kejadian yang dialami oleh seseorang meliputi kelahiran, kematian, lahir mati, perkawinan, perceraian, pengakuan anak, pengesaha anak, pengangkatan anak, perubahan nama dan perubahan status kewarganegaraan.”

\section{Pasal 56 ayat 1 :}

"Pencatatan peristiwa penting lainnya dilakukan oleh pejabat pencatatan sipil atas permintaan penduduk yang bersangkutan setelah adanya penetapan pengadilan negeri yang telah memperoleh kekuatan hukum tetap."

Undang-undang mengatur tentang perubahan kelamin dengan tidak menyebutkannya secara eksplisit, namun secara implisit dengan kata - kata peristiwa penting lainya. Penyebutan peristiwa penting lainnya terhadap pergantian kelamin menjadikannya sebagai suatu hal yang dapat diajukan dan membutuhkan pengesahan pengadilan untuk dapat berjalan sesuai jalur hukum yang berlaku. Perkara pergantian kelamin ini, pada dasarnya merupakan hak yang dimiliki oleh setiap orang, berdasarkan pada prinsip HAM internasional. Perubahan kelamin masuk dalam perkara HAM karena menurut HAM internasional, manusia juga memiliki hak untuk sehat. Dalam pengertian WHO (World Health Organisation), sehat adalah kondisi bebas dari penyakit atau kelemahan baik secara fisik, mental, dan keadaan sosial. Sedang keadaan seperti transeksual, dan atau khuntsa adalah kondisi yang dapat mendatangkan ketidaksehatan mental, sehingga dapat dianggap sebagai tidak terpenuhi haknya.

Indonesia sendiri telah menjujung tinggi HAM sesuai dengan kebiasaan, dan budaya yang berkembang di Indonesia, karena pada dasarnya HAM berkembang dan menyesuaikan kultur dari wilayah HAM diberlakukan. Indonesia mengatur HAM dalam Undang-undang nomor 39 tahun 1999, seperti menjamin warga negara mendapatkan haknya, persamaan di hadapan hukum dll. Disebutkan dalam pasal 3 ayat (2) undang-undang ini adalah setiap orang berhak atas pengakuan, jaminan, perlindungan dan perlakuan hukum yang adil serta mendapat kepastian hukum dan perlakuan yang sama di depan hukum. Dari pasal ini, dapat dikatakan, seorang

${ }^{20}$ Undang-Undang Nomor 24 Tahun 2013 tentang Administrasi Kependudukan. 
transgender (orang yang telah berganti kelamin) dapat mengajukan perubahan kelaminnya agar mendapat pengkuan resmi dari lembaga peradilan, karena kedudukannya di mata hukum dan hak untuk mendapat kepastian hukum. Meskipun didukung secara HAM, namun tidak ada undang-undang yang pasti mengenai perubahan kelamin di Indonesia. Dapat diketemukan hanya dalam Pasal 69 Undang-Undang 36 Tahun 2009 tentang Kesehatan menyebutkan: ${ }^{21}$

1) Bedah palstik dan rekronstruksi hanya dapat dilakukan oleh tenaga kesehatan yang mempunyai keahlian dan kewenangan untuk itu

2) Bedah plastik dan rekronstruksi tidak boleh bertentangan dengan norma yang berlaku dalam masyarakat dan tidak ditujukan untuk mengubah identitas

3) Ketentuan mengenai syarat dan tata cara bedah plastic dan rekronstruksi sebagaimana dimaksud pada ayat (1) dan ayat (2) ditetapkan dengan Peraturan Pemerintah

Jika melihat dari undang-undang ini, maka perubahan kelamin yang dimaksudkan untuk mengubah jenis dari laki-laki ke permpuan dan sebaliknya tidak diperkenankan sebagai disebutkan dalam pasal 69 ayat 2, yaitu tidak ditujukan untuk mengubah identitas, meskipun belum diketahui yang dimaksudkan bedah plastik dan rekonstruksi di sini adalah bedah untuk mengganti wajah saja dan atau kelamin juga.

Perbedaan dan perdebatan mengenai perubahan kelamin menurut hukum Indonesia dan Hukum Islam (norma agama) disebabkan terdapat perbedaan legal reasoning antara keduanya. Meskipun kedua hukum tersebut diawali dari perkara hukum pokok yang sama yaitu tentang "kedudukan hukum operasi ganti kelamin bagi penderita transeksual" namun antara hukum perdata dan hukum Islam berbeda. Kenyataan yang terjadi di Indonesia mengenai perubahan kelamin bagi transeksual lagi-lagi menempatkan perkara ini menjadi sesuatu yang tidak jelas kepastian hukumnya. Jika kita asumsikan bahwa perubahan kelamin tersebut adalah sesuatu yang sah saja diajukan kepada pengadilan karena tidak ada aturan pasti yang mengatur terkait tata cara dan lainnya, maka akan terdapat akibat hukum yang dimiliki oleh pelaku perubahan kelamin tersebut.

1. Akibat Hukum Perdata Perkawinan

Perkara perkawinan diatur dalam Undang-Undang Nomor 1 Tahun 1974 yang merupakan peraturan yang telah mempertimbangkan berbagai aspek hukum lain seperti hukum Islam dan hukum adat dan kemudian diadakan penyeragaman hukum yang kita sebut sebagai unifikasi. Undang-undang perkawinan, pada Pasal 1 menyebutkan bahwa perkawinan adalah ikatan lahir batin antara seorang pria dengan seorang wanita sebagai suami istri dengan tujuan membentuk keluarga (rumah tangga) yang bahagia dan kekal berdasarkan Ketuhanan yang maha esa. Dalam pasal ini terdapat tiga unsur utama dalam perkawinan yaitu, ikatan lahir batin antara seorang pria dan seorang wanita, membentuk keluarga yang bahagia, berdasarkan Ketuhanan yang Maha Esa. ${ }^{22}$

2. Akibat Hukum Kewarisan

Pergantian kelamin dalam kaitannya dengan kewarisan adalah ketika setelah operasi dan telah berganti kelaminnya, maka bagian warisnya adalah bagian waris setelah bergantinya

${ }^{21}$ Undang-Undang 36 Tahun 2009 tentang Kesehatan.

22 Marina Kurniawati, dan Herni Widanarti, “Tinjauan Yuridis Status Keperdataan Pelaku Transeksual (Studi Kasus Penetapan Pengadilan Negeri Kabupaten Semarang Nomor 518/Pdt.P/2013/PN.Ung)”, Diponegoro Law Journal, Vol. 6, No. 2 (2017), 15. 
kelamin. Namun, dalam Islam karena pergantian kelamin bagi orang normal adalah hal yang dilarang, maka bagiannya tetap pada bagian sebelum dia berganti kelamin. Kasus yang lebih kompleks seperti khuntsa musykil ditempatkan dalam waris yang lebih kecil daripada kedua kelamin, hal ini senada dengan fatwa sahabat yang didukung oleh ulama hanafiyah yang kemudian dicatut sebagai hukum di Mesir yaitu bahwa khuntsa musykil waria yang tidak diketahui dengan jelas jenis kelaminnya: lelaki atau wanita- mendapat bagian warisan yang lebih kecil (sebagai pria atau wanita). Dan sisa harta peninggalan diberikan kepada para ahli waris lainnya. ${ }^{23}$

\section{Penetapan Status Khuntsa}

Kelainan pada kelamin menimbulkan banyak pembahasan yang terkait dengannya. Kelainan kelamin seperti kelamin ganda atau Khuntsa menjadi sebuah pembahasan yang begitu menarik untuk dibahas, bukan hanya pada aspek kelainan yang terjadi pada kelaminnya dan hukumnya, namun hingga kepada aspek penanganan dan mensikapi kelainan ini, karena bagaimanapun kelamin ganda adalah permasalahan yang benar adanya dan terdapat fakta di lapangan. Hukum Islam dalam kaitannya menetapkan status khuntsa hanya berhenti kepada perkara yang dianggap terganggu ketika terdapat status abnormal seperti kelamin ganda ini, contohnya masalah waris dan pernikahan yang jelas menempatkan kejelasan kelamin sebagai sesuatu yang mutlak adanya yaitu laki-laki atau perempuan bukan diantara keduannya. Namun, ketika membahas khuntsa kaitannya dengan kehidupan yang lebih umum daripada itu, hukum Islam hanya menempatkan masalah kejelasan kelamin ini sebagai sesuatu yang mubah dan boleh diperjelas. Padahal justru permasalahannya adalah ketika kejelasan status dari khuntsa tidak menjadi perhatian khusus dan hanya diperhatikan ketika dalam masalah yang penting saja. Ketidakjelasan kelamin yang dialami khuntsa merupakan beban pikiran bagi kalangan yang mengalaminya. Hal ini dipengaruhi oleh pemikiran perkembangan gender yang harusnya menjadi jelas dalam rentang waktu tertentu.

Kohlberg menerangkan bahwa dalam teori perkembangan gender terdapat tiga fase yang sangat penting: ${ }^{24}$

1. Gender identity, fase ini terjadi pada kisaran usia dua hingga tiga tahun. Pada fase ini, seseorang dapat mengenali dan melabeli diri sebagai laki-laki atau perempuan. Pada fase ini pula pola pikir dan perilaku individu di masa depan akan terbentuk sesuai dengan jenis kelaminnya.

2. Gender stability, fase ini terjadi pada kisaran usia empat hingga lima tahun. Fase ini dialami individu untuk kemudian dapat mengenali dan memahami sifat alami dari suatu jenis kelamin seperti laki-laki kencing dari penisnya dan perempuan dari saluran pada vaginanya, meskipun belum terlalu mengerti secara rinci mengenai kemampuan kelaminnya.

${ }^{23}$ Yusuf Qardhawi,. Hadyul Islam Fatawi Mu'ashirah, alih Bahasa Abdul Hayyie, dkk., (Jakarta: Gema Insani Press, 2001), 466.

${ }^{24}$ Steffi Kurniawan dan Meilina Imelda, "Gangguan Identifikasi Jenis Kelamin.” CDK-210, Vol. 40, No. 11, (2013), 828 . 
3. Gender consistency, fase ini terjadi pada kisaran usia enam hingga tujuh tahun. Pada fase ini, individu mulai mengerti bahwa kelamin adalah sesuatu yang alamiah dan didapatkan ketika lahir, maka kelamin tidak dapat diubah.

Rentang usia dalam pengenalan gender membuat kejelasan tentang identitas gender menjadi sesuatu yang harus dimiliki oleh setiap individu. Kelamin ganda dalam pandangan ini menjadi sebuah kasus yang tidak dapat dibiarkan terjadi, karena dapat mempengaruhi pola pikir dari seorang yang berkelamin ganda. Selain dari aspek usia dalam pengenalan diri, pengaruh lingkungan juga memberikan andil dalam pengenalan gender. Hal ini disebutkan dalam teori perkembangan gender sebagai berikut: ${ }^{25}$

1. Teori Psikoanalitik

Teori ini dikemukakan oleh Freud yang menyatakan bahwa jenis kelamin anak ditentukan fase falik. Perasaan takut terhadap kastrasi menjadi batu loncatan untuk kemudian anak mulai mengidentifikasi orang tua yang memiliki jenis kelamin yang sama. Dengan berdasar pada teori yang berbeda dari teori gender yang mengedepankan faktor biologis, Freud menetapkan bahwa mekanisme dasar kepribadian yang kaitannya dengan gender diperoleh melalui identifikasi dengan orang tua yang berjenis kelamin yang sama dengan dirinya, dan hal ini terjadi secara alamiah.

2. Teori Lingkungan/Environmental

Teori ini menjelaskan bahwa perkembangan gender tergantung pada teori belajar dengan mengusung tiga elemen yang harus ada yaitu; stimulus, respon terhadap stimulus, dan perilaku yang dihasilkan. Teori pembelajaran menenmpatkan individu sebagai organisme pasif yang memperluas perilaku dengna pengalaman. Kaitannya dengan perkembangan gender, bahwa anak (dalam rentang waktu tertentu) belajar mengidentifikasi jenis kelamin berdasarkan reaksi orang sekitar terhadap perilaku dan bahkan kelamin fisik anak.

3. Teori Kognitif

Teori ini menjelaskan bahwa perkembangan jenis kelamin terbentuk oleh kemampuan kognitif pada anak. Teori kognitif dibedakan menjadi dua, yaitu teori kognitif-lingkungan dan developmental-konstruktif. Kognitif-lingkungan terjadi ketika meningkatnya interaksi antara lingkungan dan karakteristik personal. Sedang pada teori kognitif-konstruktif, individu menjadi aktif untuk mendapatkan, mengatur dan menggunakan informasi pada kehidupan sosialnya.

4. Esensialisme Gender

Teori ini menjelaskan bahwa letak perbedaan terbesar pada kelamin adalah adanya faktor genetika, hormone dan neurologis. Sebagai contoh dari inti letak teori ini adalah adanya perbedaan jenis kelamin dengan memperhatikan ciri-ciri dan karakteristik yang ditunjukkan oleh pria dan wanita pada zaman purba, begitu pula ada pula yang didasarkan

25 Tomer Shechner. "Gender Identity Disorder: A Literature Review From A Developmental Perspective." The Israel Journal of Psychiatry and Related Sciences, Vol. 47, 2 (2010): 135. 
pada studi perkembangan neurofisiologis dan juga faktor biologis dalam pembentukan kelamin.

Pokok teori perkembangan gender menjadi sebuah tanda bahwa identitas gender tidak hanya terbatas pada pengenalan individu terhadap kelamin fisiknya, namun juga dipengaruhi pikiran bawah sadar serta lingkungan untuk mengenali gendernya. Hal ini tentu menjadi masalah dalam kasus seperti kbuntsa atau individu yang berkelamin ganda, karena pada kelamin fisik saja, tidak jelas antara dia laki-laki dan perempuan. Dengan ketidakjelasan kelamin fisik ini, maka pandangan orang disekitarnya pun dapat menjadi tidak positif, ini dapat berpengaruh terhadap pengenalan identitas dan gender yang ada pada dirinya menurut pada teori perkembangan gender.

Maka, penetapan identitas gender terutama untuk kelamin fisiknya harus diperjelas dan diperkuat seutuhnya sebelum terjadi kerancuan dan ketidaknyamanan pada dirinya terkait status kelaminnya yang tidak jelas ini. Urgensi penetapan kelamin pada khuntsa harus mendapat tindakan istimewa agar menjadi sebuah hal yang dapat menjadi solusi bagi khuntsa dan menjadi sebuah tindakan tepat agar mengurangi kemadharatan di kemudian hari, baik dalam hal agama dan atau sosial. Kepentingan untuk menetapkan status bagi khuntsa sejak dini merupakan perwujudan dari maqashid Syariah yaitu mendatangkan kemaslahatan dalam lima hal utama (dharuri).

Pendapat mengenai pentingnya untuk menentukan dan menetapkan status khuntsa berlandaskan pada kaidah fiqhiyyah yaitu الضرريزال, kemadharatan harus dihilangkan. ${ }^{26}$ Khuntsa adalah sebuah hal yang menjadikan kemadharatan bagi individu yang mengalami, meskipun itu bersifat alamiah dan tidak dibuat. Selain itu, dewasa ini, teknologi sudah mendukung untuk dapat menghilangkan kemadharatan yang diderita oleh khuntsa, maka dapat kita mengerti bahwa ketika sebuah kemungkinan untuk menghilangkan kemadharatan sudah dapat dilakukan secara pasti, kemadharatan tersebut harus dihilangkan. Turunan dari kaidah ini juga dapat dijadikan landasan hukum untuk menetapkan status khuntsa secara lebih jelas, yaitu "menghindarkan kerusakan lebih didahulukan daripada mencari maslahat." 27

Menghindarkan akibat yang dapat ditanggung oleh khuntsa yang berupa hal negatif, dapat menyebabkan kemadharatan yang besar. Senada dengan pendapat Al-Suyuti yang dikutip dari kitab Al-Jami' oleh Kutbuddin Aibak bahwa dalam hal operasi kelamin dalam kasus khuntsa yaitu bahwa kaidah ini dapat menjadi dalil bolehnya dilaksanakannya operasi kelamin pada khuntsa dengan alasan bahwa kemadharatan yang dapat ditimbulkan dari tidak dilaksanakannya operasi kelamin bagi khuntsa adalah dapat mengalami kelainan psikis dan sosial yang berujung pada terjerumusnya khuntsa kepada pelacuran dan menjadi sasaran serta incaran kaum gay yang jelas merupakan individu yang menyimpang menurut agama dan sosial kemasyarakatan. Ketika teknologi telah memungkinkan untuk melakukan operasi kelamin, maka sangat dianjurkan untuk melakukannya bagi khuntsa untuk menghindari kemudharatan yang lebih besar dikemudian hari apabila dibiarkan. Dharar bermakna ketakutan seseorang pada bahaya yang menngancam nyawa atau kesusahan yang teramat sangat menurut Abu Bakar Al-Jashas. Selain itu dharar dapat

${ }^{26}$ Abdul Karim Zaidan, Al-Wajiz fii Syarbil Qawaid Fiqbiyyah fii Syariah Islamiyah, (Beirut: Risalah Publisher, 2001), 88.

27 Ibid., 88 . 
bermakna kekhawatiran terhadap diri dari kematian atau hal yang menyusahkan baik berdasar keyakinan atau hanya sekedar dugaan.

Dengan demikian dharar yang dimaksudkan untuk dihindari adalah kesulitan yang sangat menentukan eksistensi manusia, karena apabila tidak diselesaikan atau dihindarkan maka akan mengancam lima maqashid dharuriy yaitu agama, jiwa, nasab, harta serta kehormatan manusia baik salah satunya ataupun kesemuannya. Khuntsa jika merunut dari maksud dari dharar tersebut maka dapat dikategorikan sebagai dharar, karena dapat menyebabkan kekhawatiran kepada orang yang mengalaminya. Kekhawatiran tersebut dapat berupa kekhawatiran kepada hal yang berupa fisik ataupun secara mental, karena batasan pada dharar tidak dibatasi hanya kepada yang terlihat atau fisik, namun juga kepada yang tidak terlihat yaitu mental. Penetapan status bagi kbuntsa apabila tidak dianggap sebagai sesuatu yang penting dan urgen, tentu akan mendatangkan madharat yang berpengaruh terhadap kehidupan dari khuntsa itu sendiri seperti telah dibahas sebelumnya. Kemadharatan tersebut dapat berupa perlakuan yang buruk kepadanya dan dapat pula berimbas kepada stress. Yang menjadi masalah adalah apabila jumlah stres begitu banyak dapat membahayakan kondisi fisik dan mental seseorang. ${ }^{28}$

\section{KESIMPULAN}

Khuntsa merupakan suatu keadaan genital abnormal yang memerlukan penanganan khusus. Penanganan khusus yang dimaksudkan bukan hanya sekedar sebagai pemecahan akibat-akibat yang ditimbulkan dengan kondisi kbuntsa tersebut, namun juga meliputi pada penanganan terhadap individu khuntsa tersebut. Penetapan status khuntsa juga merupakan penanganan khusus terhadap kondisi abnormal ini. Urgensi dari penetapan status ini dimaksudkan agar khuntsa dapat terhindar dari hal-hal negatif yang dimungkinkan dapat berakibat sangat fatal terhadap kondisi psikis dan bahkan fisik.

Kemungkinan ini didasarkan pada beberapa teori psikologis yang mengatakan bahwa pengenalan terhadap gender telah dimulai ketika individu berada pada jenjang usia yang muda, dan pengenalan ini didukung oleh beberapa faktor diantaranya 1) Identifikasi alami individu terhadap kelamin yang dimilikinya, 2) perlakuan dari orang-orang disekitarnya terhadap dirinya. Kedua faktor dalam pengenalan identitas gender ini tidak terdapat pada kondisi seperti kbuntsa dikarenakan ketidakjelasan pada kelaminnya ditambah dengan streotip yang cenderung negatif terhadap kondisi abnormal ini.

Dengan demikian semakin menjadi keniscayaan untuk kemudian menetapkan status Khuntsa dengan lebih dini untuk mencegah akibat yang lebih parah daripada ketidaktahuan individu khuntsa terhadap gendernya. Urgensi ini didukung dengan kaidah fikih yaitu الضرر يز ال atau kemadharatan harus dihilangkan, karena dengan akibat yang sedemikian rupa, kondisi khuntsa menjadi sebuah madharat bagi individunya.

Terlebih dunia kedokteran telah mendukung untuk dapat melakukan penegasan status bagi khuntsa melalui jalan operasi penyempurnaan kelamin dan hal ini memungkinkan untuk dilakukan. Walau demikian, dalam pengkajian hukum Islam tidak diperbolehkan untuk langsung menetapkan perubahan kelamin, dengan alasan merubah ciptaan Tuhan.

${ }^{28}$ Nasib Tua Lumban Gaol, “Teori Stres: Stimulus, Respons, dan Transaksional.” Buletin Psikologi Vol. 24, No. 1 (1 Juni 2016): 1. https://doi.org/10.22146/bpsi.11224 
Perubahan kelamin yang terjadi harus memenuhi syarat secara syariat dan fikih modern. Salah satu syarat untuk merubah kelamin pada fikih modern adalah apabila jika tidak dirubah kelaminnya, maka madharat yang terjadi besar. Di sisi lain, perubahan kelamin menurut kedokteran, tidak dapat dilakukan dengan mudah dan cenderung menempuh waktu yang lama (hingga 6-9 kali operasi). Maka, dengan demikian, menetapkan status baik dengan operasi atau tanpa operasi menjadi jalan yang tidak menimbulkan madharat yang telah dipaparkan di atas.

Melihat syarat secara syariat maupun fikih tersebut di atas, hal ini sejalan dengan pandangan bahwa kelamin ganda menjadi sebuah kasus yang tidak dapat dipandang sebelah mata atau hanya dibahas pada saat terjadi permasalahan lain yang timbul akibat tidak jelasnya status khuntsa tersebut. Melihat pendapat Kohlberg, bahwa terdapat tiga fase pengenalan gender yang sangat penting, yaitu: 1) Gender identity (umur 2-3 tahun), fase seseorang dapat mengenali dan melabeli diri sebagai laki-laki atau perempuan, serta terbentuknya pola pikir dan perilaku individu, 2) Gender stability (umur 4-5 tahun), fase ini dapat mengenali dan memahami sifat alami dari suatu jenis kelamin seperti laki-laki kencing dari penisnya dan perempuan dari saluran pada vaginanya, meskipun belum terlalu mengerti secara rinci mengenai kemampuan kelaminnya, 3) Gender consistency (umur 6-7 tahun), fase ini mulai mengerti bahwa kelamin adalah sesuatu yang alamiah dan didapatkan ketika lahir, maka kelamin tidak dapat diubah.

Oleh karenanya, rentang usia pada masa pengenalan gender membuat kejelasan identitas gender menjadi sesuatu yang harus dimiliki oleh setiap individu dan menjadikannya sesuatu yang harus ditetapkan statusnya sejak usia dini bagi seorang khuntsa.

\section{REFERENSI}

Abdul Aziz, Shalih. 1996. at-Takmil Mafata Tahribibi min Idwaul Ghalil. Riyadh: Darul Asshimat.

Ali, Atabik, dan A. Z. Muhdor. 1996. "Kamus Kontemporer.” Yogyakarta: Yayasan Ali Maksum Pondok Pesantren Krapyak, 1996.

Davies, Kate. 2016. "Disorders of Sex Development-Ambiguous Genitalia." Journal of Pediatric Nursing 31, no. 4 (Juli 2016): 46-66. https://doi.org/10.1016/j.pedn.2016.04.007.

Kulaini. 1367. al-Kaafi. Juz 7. Iran: Darul Kitab Islamiyah, 1367.

Kurniawan, Steffi, dan Meliana Imelda. 2013. "Gangguan Identifikasi Jenis Kelamin.” CDK-210, Vol. 40, No. 11, (2013).

Kurniawati, Marina, dan Herni Widanarti. 2017. “Tinjauan Yuridis Status Keperdataan Pelaku Transeksual (Studi Kasus Penetapan Pengadilan Negeri Kabupaten Semarang Nomor 518/Pdt.P/2013/PN.Ung)", Diponegoro Law Journal, Vol. 6, No. 2 (2017).

Lumban Gaol, Nasib Tua. 2016. “Teori Stres: Stimulus, Respons, dan Transaksional.” Buletin Psikologi, Vol. 24, No. 1 (2016). https://doi.org/10.22146/bpsi.11224.

Putro, Bagus Prasetyo Purnomo. 2013. “Tinjauan Yuridis Perkawinan Al-Khuntsa (Kelamin Ganda) Menurut Hukum Islam,” (Skripsi Sarjana, Universitas Jember, 2013). 
Qardhawi, Yusuf. 2001. Hadyul Islam Fatawi Mu'ashirah. Alih Bahasa Abdul Hayyie, dkk., Jakarta: Gema Insani Press.

Rahman, Fathur. (1975). Ilmu Waris. Bandung: al-Ma'arif.

Sabiq, Sayyid. 2004. Fiqih Sunnah. Alih Bahasa Nor Hasanuddin, Cet. 3, Kairo: Darul Fath.

Saraswati, Devie Lya. 2017. "Eksplorasi Kepribadian Waria dalam Perspektif Psikologi Individual." Jurnal Riset Mabasiswa Bimbingan dan Konseling 1 (2017).

Shechner, Tomer. 2010. "Gender Identity Disorder: A Literature Review From A Developmental Perspective." The Israel Journal of Psychiatry and Related Sciences, Vol. 47, 2 (2010): 132-138.

Susanto, Edy, dkk. 2013. “Hermaphrodite Sejati.” Makalah Obstetri \& Ginekologi, Vol. 21, No. 1, (Januari-April, 2013).

Syarifuddin, Amir. 2004. Hukum Kewarisan Islam. Jakarta: Prenada Media.

Undang-Undang Nomor 36 Tahun 2009 tentang Kesehatan

Undang-Undang Nomor 24 Tahun 2013 tentang Administrasi Kependudukan.

Yuliasri, Ni Luh Tanzila. 2018. "Kedudukan Ahli Waris Khuntsa dalam Hukum Waris Islam". Mimbar Keadilan, Vol. 14, No. 28, (1 Agustus 2018): 208-219. https://doi.org/10.30996/mk.v0i0.1781

Zaidan, Abdul Karim. 2001. Al-Wajiz fii Syarbil Qawaid Fiqhiyyah fii Syariah Islamiyah. Beirut: Risalah Publisher.

Zuhaili, Wahbah az-. 1985. al-Fiqbu al-Islam wa Adillatubu, Cet. II, Jilid VIII. Beirut: Darul Fikr.

Zuhdi, Masjfuk. 1991. Masail Fiqhiyyah: Kapita Selekta Hukum Islam. Jakarta: CV. Haji Masagung.

Zuhroni, Nur Riani, dan Nirwan Nazaruddin. 2003. Islam untuk Disiplin Ilmu Kesehatan dan Kedokteran 2, Jakarta: Departemen Agama RI. 